defined media, with the view of its possible application to the chemotherapy of nematode infections; Dr. Evelyn E. B. Smith (University of Glasgow), to investigate, at the Department of Biochemistry, Glasgow, the enzymic mechanisms of transfer reactions involving uridine pyrophosphate compounds containing glucose, glucuronic acid and $\mathrm{N}$-acetylglucosamine, and to study the biosynthesis of glucuronic acid, glucuronides and oligosaccharides containing glucuronic acid, using carbon and phosphorus isotopes.

\section{Lady Tata Memorial Trust: Awards}

THE following awards have been made by the Lady Tata Memorial Trust for research on leukæmia and allied diseases, to be conducted in the places indicated during the academic year beginning October 1, 1953. Grants for research expenses or for scientific assistance: Dr. A. Fagraeus and Dr. B. Thorell (Stockholm), Dr. C. Merskey (Cape Town), Prof. C. Oberling (Villejuif, Seine) and Dr. C. C. Ungley (Newcastle upon Tyne), renewals ; Dr. J. Nordmann (Paris), new award. Part-time personal grant and grant for technical assistance: Dr. J. B. G. Dausset (Paris), renewal with increase. Senior Research Fellowships: Dr. A. R. Gopal-Ayengar (London), extension for two months; Dr. J. Kieler (Copenhagen), new award. Scholarships (whole-time or part-time): Dr. R. Rask-Nielsen (Copenhagen) and Dr. R. Robineaux (Paris), renewals; Dr. F. Kissmeyer-Nielsen (Aarhus) and Dr. N. A. Stenderup (Aarhus), new awards. In addition, the period of tenure of a special scholarship awarded earlier this year to Dr. Gavino Negroni (Italy), for work at the Imperial Cancer Research Fund Laboratories, Mill Hill, London, will continue until April 30, 1954.

\section{University of Birmingham: Appointments}

THE following have been appointed lecturers in the University of Birmingham: Dr. J. H. Cort (physio$\operatorname{logy}$ ), Miss Joyce B. Grace (bacteriology), Dr. T. O. Jeffries (physics), J. B. Woodward (mathematical physics) and Dr. K. White (physiology). The following have resigned from the University : F. R. N. Nabarro, lecturer in metallurgy, on appointment to the chair of physics in the University of the Witwatersrand, Johannesburg; and Dr. A. B. L. Beznak, lecturer in physiology, on appointment to the chair of physiology in the University of Ottawa.

\section{American Academy of Arts and Sciences: Foreign Honorary Members}

THE following have been elected foreign honorary members of the American Academy of Arts and Sciences: Prof. Arne Tiselius, professor of biochemistry, University of Upsala; Prof. A. J. Kluyver, professor of microbiology, Technical University, Delft ; and Prof. D. M. S. Watson, formerly Jodrell professor of zoology and comparative anatomy, University College, London.

\section{Meeting of Nobel Prize-winners in Lindau}

Meetings of Nobel prize-winners were started some years ago at Lindau, Bavaria, on the shores of Lake Constance, for the purpose of creating and developing a general contact between leading scholars in an exact science and the professional and industrial workers whose daily work is based on the results of the investigations of these scientists. The method chosen for achieving this contact is for the Nobel
Laureates to give lectures adapted in their content to the needs of practical men and giving a survey on the results of scientific research to the layman. The meeting this year, to be held during June 29 -July 2 under the patronage of Count Lennart Bernadotte, is devoted to physics, and eight lectures will be given as follows : June 29, Prof. M. von Laue (Röntgen-ray interferences) and Prof. G. von Hevesy (biochemical effects of ionizing radiations); June 30, Prof. $O$. Hahn (modern alchemy) and Prof. C. F. Powell (high-altitude flights with free balloons); July 1, Prof. F. Soddy (discovery of the natural transmutation of the radio-elements) and Prof. P. A. M. Dirac (quantum mechanics and the æther); July 2, Prof. H. Yukawa (search for a unified theory of elementary particles) and Prof. W. Heisenberg (progress and difficulties in the quantum theory of elementary particles). The general arrangement is for lectures to be given during the morning so as to leave the rest of the day free for discussion groups and for excursions and other social activities. The fee for participation in the meeting is DM 30 or DM 10 a day. Further information can be obtained from the Sekretariat der Tagungen der Nobelpreisträger, Stadttheater, LindauBodensee.

\section{Announcements}

Dr. L. C. BAtEMaN, deputy director of research and formerly superintendent of chemical research of the British Rubber Producers' Research Association, has been appointed director of research of the Association in succession to Dr. Geoffrey Gee, now professor of physical chemistry in the University of Manchester.

Dr. ERNST MAYR, curator of the Whitney-Rothschild Collection, American Museum of Natural History, has been appointed Alexander Agassiz professor of zoology in the Museum of Comparative Zoology, Harvard University. Two other appointments are those of Mr. James C. Greenway, jun., to be curator of birds in the Museum in succession to the late James L. Peters, and Mr. Raymond A. Paynter, jun., to be assistant curator of birds.

THE Philosophy of Science Group of the British Society for the History of Science is offering a prize of $£ 50$ for the best essay of not more than 4,000 words on: "What is the logical and scientific status of the concept of the temporal origin and age of the Universe?" (for example, as used in recent cosmological work). The essay should elarify the logical, theoretical, and observational aspects of the idea of assigning a quantitative age to the universe. Essays in English, French or German (in typescript) must reach the Honorary Secretary, Philosophy of Science Group, University College, Gower Street, London, W.C.I, not later than December 1, 1953, must bear a pseudonym, and be accompanied by a closed envelope containing the pseudonym and the author's name. Essays submitted will be treated as material offered to the British Journal for the Philosophy of Science.

Errata. In the article entitled "Food Products from Plants" in Nature of May 23, p. 917, paragraph 3 , line 3, for " $0.069 d$. per lb. of protein, compared with $0-8 d$. per lb. of protein from beef", read " $0.069 d$. per gm." and " $0 \cdot 8 d$. per gm.", respectively. 